\title{
Bilgisayar destekli eğitimle öğrenme: Bir meta-tematik analiz
}

\author{
Veli BATDI ${ }^{1}$, Özgür ANIL ${ }^{2 *}$ \\ ${ }^{l}$ Gaziantep Üniversitesi, Gaziantep Eğitim Fakültesi, Eğitim Bilimleri Bölümü, Gaziantep. \\ ${ }^{2}$ Milli Savunma Üniversitesi, Kara Harp Okulu, Temel Bilimler Bölümü, Ankara.
}

Geliş Tarihi (Received Date): 18.04.2020

Kabul Tarihi (Accepted Date): 17.07.2020

$\ddot{\mathbf{O z}}$

Bu çalışmanın amacl, bilgisayar destekli eğitimin (BDE) etkisini meta-tematik analiz. çerçevesinde belirlemektir. Bu amaçla, Yüksekögretim Kurulu Tez Merkezi ve Google Akademik veri tabanlarından faydalanılarak 2009-2020 yıl aralığında yapılan BDE konulu nitel çalışmalar analize dâhil edilmiştir. Doküman incelemesine dayalı toplanan veriler içerik analizinden faydalanılarak çözümlenmiştir. Araştırma sonunda, BDE'nin akademik gelişime, tutuma, teknolojiyi kullanma becerilerine etkisi ile BDE'nin sınırlılıklarına değinen temalara ulaşılmıştır. BDE'nin katkıları noktasında dersi sevme, motivasyon, ilgi ve istek açısından gelişme kaydetmeyi sağladiğ kullanabilmeye pozitif yönde etkilerinin olduğu anlaşılmıştır. Belirtilen teknik problemler, sağlı sorunları ve bilgisayar kullanabilme yetersizliği gibi bazı sinırlılıklarına rağmen, bu yöntemle öğrenme sürecinin verimli ve istendik yönde sürdürülebileceği algılanmıştır. Araştırma sonucunda sunulan bazı önerilere ek olarak $B D E$ 'nin zaman ve mekân sınırı tanımadan, kapsamındaki zengin içeriğiyle ögrenme ortamına canlılık ve kalıcılık sunacă̆ı düşünülmektedir.

Anahtar Kelimeler: BDE, meta-tematik analiz, akademik gelişim, tutum, teknoloji, sinirlilık.

Veli BATDI, veb_27@hotmail.com, http://orcid.org/0000-0002-7402-3251

* Özgür ANIL, ozguranil1@yahoo.com, http://orcid.org/0000-0002-2886-0817 


\title{
Learning by computer-based education: A meta-thematic analysis
}

\begin{abstract}
The aim of this study is to determine the effect of computer-based education (CBE) within the framework of meta-thematic analysis. For this purpose, qualitative studies on CBE including the years of 2009-2020 are selected for the analysis by using the Higher Education Council Thesis Centre and Google Scholar databases. The data collected based on the document review was analyzed using the content analysis. Following the collection of the data, the themes addressing the limitations of CBE, the effect of CBE on academic development, attitude and technology usage skills were reached. It was understood that CBE contributed to the development of motivation, interest, desire and love of the lesson, and has also a positive effect on using technology consciously. Despite some of its limitations like technical and health problems, inability to use computers, it has been perceived that the learning process can be continued efficiently and in the desired direction with this method. In addition to some suggestions presented as a result of the research, CBE is thought to offer vitality and permanence to the learning environment with its rich content without the time and place limit.
\end{abstract}

Keywords: CBE, meta-thematic analysis, academic development, attitude, technology, limitation.

\section{Giriş}

Yirminci yüzyılla birlikte teknolojik gelişmelerin hız kazanması sonucu dünyada birbirini takip eden önemli gelişmeler yaşanmıştır. Hayatın her alanına nüfuz etmeye başlayan teknoloji, eğitim alanında da kendisine yer bulmuş ve eğitim sürecine dâhil olmuştur. Bilgisayarın günlük hayatımıza girmesi yaşamımızı kolaylaştırmış ve günlük hayatımızda bilgisayar kullanım alanlarının genişlemesiyle birlikte toplumsal yaşantımız da buna göre yön bulmuştur. Teknolojik aletlerin başında gelen bilgisayar hemen hemen eğitimin her alanında kullanılmaya başlanmıştır [1]. Çünkü eğitim sürecinde kullanılan bilgisayar, hem öğretmenler için büyük bir yardımcı materyal olmuş hem de birden çok duyuya hitap ederek öğrencilerin dikkatini çekmiştir. Dolayısıyla bilgisayar kullanımı eğitimde artık bir yöntem hâline gelmiş ve günümüzde eğitim sürecinin kaçınılmazlarından biri haline gelmiştir.

Bilgisayar teknolojisi, eğitim programlarının tüm seviyelerinde öğretmen kalitesi ve öğrenci başarılarını desteklemeye yardımcı olan bir araç olarak belirtilebilir. Bilgisayarlar, ilk kez 1950'li yıllarda uygun programlar geliştirilmesiyle öğrenme sürecine dâhil edilmiştir [2]. Eğitim-öğretim sürecinde bilgisayar tek başına değil, farklı materyallerle beraber kullanılmaktadır. Bunun yanında bilgisayar, diğer teknolojik aletlerle birlikte kullanılarak daha etkili bir materyal hâline dönüşsebilmektedir. Bilgisayar, bireysel öğrenme ortamı sunmada ve bilginin kalıcı olarak öğrenilmesinde önemli bir eğitsel materyaldir [3]. Dolayısıyla, bilgisayarların öğrenme sürecindeki kullanımı bilgisayar destekli/temelli öğrenme/eğitim/öğretim gibi isimlerle eğitimde etkili yöntemlerden biri olarak kullanılmaktadır. BDE kaynağını bireye dayandırmakta olup amacı eğitimi bireyselleştirmektir [4]. Bilgisayar destekli eğitim (BDE) ile çocuklar, 
kendi öğrenme hılarında bilgiye ulaşabilmekte ve öğrenme sürecinden daha fazla faydalanabilmektedirler. Bilişsel gelişimi desteklemesi bakımından bilgisayarlar; çocukların zihinsel süreçlerde daha aktif olmasını sağlayarak öğrenme sürecine katkı sağlayıp soyut deneyimleri somutlaştırmaktadır. Aynı zamanda bilgisayarlar, çocukların zihinsel dünyalarını yaratıcı bir şekilde gelişmesine imkân sunmaktadır [3]. BDE'de öğretmen temel öğretici; bilgisayar ise ders içeriklerinin ve etkinliklerinin sunulduğu bir materyaldir [5]. Bilgisayar aracılığıyla sunulan eğitim, sınıf ortamında öğretmen ve öğrenci arasında bir bağ kurarak eğitim sürecini öğretmen merkezli durumdan öğrenci merkezli duruma getirmektedir [6]. Bu sayede öğrenci kendini daha yetkin hissederek sürece daha aktif katılım sağlamaktadır.

\section{BDE ve öğrenme süreci arasındaki ilişki}

Çocuklar; yaş gruplarına göre kavramları tanımlama, sınıflandırma ve değerlendirme işlemlerini gerçekleştirmektedir [7]. Okul öncesi dönem, Piaget'e göre işlem öncesi dönemi içerisine alan bir süreçtir. $\mathrm{Bu}$ dönemde çocuk soyut kavramları anlayamamaktadır. Soyut kavramların öğretiminde somutlaştırma, büyük bir öneme sahip olduğu için okul öncesi dönemde bilgisayarların kullanılması önemlidir [8]. Çünkü erken çocukluk dönemi, hayatın başı ve zihinsel gelişimin en hızlı olduğu süreçtir [9]. Bu dönemde, çocuğun zengin uyarıcılara sahip bilgisayarla eğitim görmesi çocuk için faydalı olmaktadır. Ayrıca öğrenme sürecinde çocuğun yaptığı davranışa anında dönüt vermeleri bakımından da bilgisayarlar büyük bir öneme sahiptir. Bilgisayarlar; resim, video, müzik, renkli grafikler ve kullanan kişiye anında dönüt vermesiyle öğrenme-öğretme sürecini zenginleştirmektedir [10]. Öğrenme sürecinde yaptığı davranışın doğru olup olmadığı konusunda bilgisayar tarafından uyarılan öğrenci, amacına ulaşmak için gerekli düzenlemeleri yapıp tam bir öğrenme gerçekleştirmektedir.

BDE ile çocuklar mantıklı düşünmeyi kazanmakta ve keşfederek öğrenmektedir. Okul öncesinde başlanan BDE ile ilk sinıflardan itibaren çocuklar programlamayı öğrenmektedir [11]. BDE'de yaygın olarak kullanılan beceri programları çocukların sorulara doğru veya yanlış yanıt verip vermediğini görmesini sağlayarak öz-kontrol ve öz-değerlendirme yapabilmelerine imkân tanımaktadır [12]. Ayrıca okul öncesi dönemde de beceri programlarının kullanılması çocuklara yaptığı davranış hakkında dönütler vermesi ve öğrenciyi öğrenme sürecinde aktif kılması açısından önemlidir. Bu dönemde BDE'de kullanılan yazılımlar, eğitici ve öğretici olmasının yanında aynı zamanda motive eden, öğrenciyi aktif kılan bir yapıda olmalıdır [13]. Okul öncesi dönemde, çocuklar okuma ve yazma becerilerine sahip olmadığından BDE'de kavram ve programlarının görsel uygulamaları içermesi önem taşımaktadır [14]. Bu sebeple, hazırlanan yazılımların ses ve görseller taşıması çocukların eğitim sürecinde kavramları doğru şekilde algılamalarına ve öğrenmelerine yardımcı olacaktır.

Bilgisayar sadece sınıf ortamına bağlı kalmayıp duvarları aşarak iletişim becerisini destekleyen, üst düzey düşünme becerisini geliştirici ve öğrencilerin karmaşık problemleri çözmelerine olanak sağlayan bir materyaldir [15]. İlkokullarda bilgisayarların kullanımıyla öğrenilenlerin daha kalıcı olduğu, derslerin daha zevkli hale geldiği, somutlaştırma yapıldığı ve hayal dünyasının geliştiği anlaşılmaktadır [16]. Okul öncesinde olduğu gibi ilkokulda da BDE öğrencilerin bilişsel ve duyuşsal yönden gelişimlerini desteklemektedir. Özellikle kalıcı öğrenme sağlama, hayal dünyasını geliştirme ve dersleri zevkli hale getirme gibi özelliklerle BDE öğrencilerin gelişimlerine 
katkı sağlamaktadır. Dünyada Almanya, Amerika, Fransa, Hollanda, İngiltere, İsveç, İspanya, Japonya, Norveç ve Rusya gibi pek çok ülke de bu alanda kendilerini geliştirerek öncü duruma gelmiştir [12]. Ülkemizde ise eğitim- öğretim alanında bilgisayarlar 1984 yılında Milli Eğitim Bakanlığının oluşturmuş olduğu komisyondan geçerek kullanılmaya başlanmıştır. 1985 yılında 1100 tane bilgisayar liselere dağıtılmış ardından 1989-1993 yılları arasında ise daha hızlı gelişmeler yaşanarak 2001 yılına kadar her okula bilgisayar laboratuvarı kurulması amaçlanmıştır [17]. Bu gelişmeler BDE yönteminin daha yaygın kullanılmasına imkân tanımıştır.

\subsection{Alanyazında BDE çalışmaları}

Ülkemizde BDE üzerine yapılan çeşitli araştırmalar bulunmaktadır. Kaçar ve Doğan [4], yapmış oldukları çalışmada okul öncesi eğitimde BDE'nin rolünü araştırmıştır. BDE ve geleneksel eğitim uygulanarak okul öncesi döneme devam eden çocukların geometrik şekil ve sayı kavramlarını öğrenme başarıları incelenmiştir. Araştırmada bilgisayar desteği ile sunulan eğitimin geleneksel eğitimden daha başarılı ve etkili olduğu sonucuna ulaşılmıştır. Ancak çalışmada okuma-yazma bilmeyen çocukların bilgisayar kullanma noktasında zorluk yaşayabilme ihtimalleri ve bilgisayarda geçirilen süre hususlarının dikkate alınması gerektiği belirtilmiştir. Buna ek olarak Aladağ [18] yapmış olduğu çalışmada BDE'nin çocukların ilk okuma-yazma becerilerini destekleyici bir etkiye sahip olduğu sonucuna ulaşmış ve Ovalı [19] çalışmasında 8. Sınıf öğrencilerinin Türkçe dersine yönelik başarılarında BDE'nin etkisini inceleyerek araştırma sonucunda BDE'nin geleneksel yönteme göre daha etkili ve başarılı olduğu sonucuna ulaşılmıştır. Şen [20] ise bir ortaokul 7. Sınıfta müzik öğretiminde kullandığ1 BDE'nin etkili ve eğlenceli olduğu, ögrenci açısından aktiflik sağladığı sonucuna ulaşılmıştır. Sakallı'nın [21] Milli Eğitim Bakanlığına bağlı bir ortaokulda matematik öğretiminde bilgisayar destekli proje tabanlı öğretimle geleneksel yöntemi karşılaştırdığ görülmüştür. Araştırma sonucunda bilgisayar destekli proje tabanlı matematik eğitimin geleneksel yönteme göre öğrencilerin akademik başarılarını arttırdığı anlaşılmıştır. Çevik [22] yürüttüğü çalışmada kimya eğitiminde farklı lise türlerinde görev yapan öğretmen görüşlerini inceleyerek araştırma sonucunda BDE'nin kimya öğretimini kolaylaştırdığına ulaşmıştır. Yapılan çalışmalara bakıldığında okul öncesi dönemden yükseköğrenime kadar bireylerin eğitimsel sürecinde bilgisayar temeli eğitimin etkili olduğu sonucuna ulaşılmıştır.

Uluslararası alanyazın incelendiğinde ise, Kulik ve Kulik [23] tarafindan BDE'nin etkililiğine ilişsin yürütülen bir meta-analiz çalışmasına rastlanmıştır. Bu çalışmada, anasınıfından üniversite düzeyine kadar olan çalışmaların analize dâhil edildiği görülmüştür. Bu yöntem kullanılarak işlenen derslerde, sınav puanlarının 0.30 düzeyinde artış gösterdiği, bu sonucun başarıyı orta düzeyde, anlamlı ve pozitif yönde etkilediği anlaşılmıştır. Diğer yandan, Morrison ve ark. [24] ise BDE başarısıyla uygulamada sunulan dönüt ve teşvik arasındaki ilişkiyi incelemişlerdir. Bu çalışmalarında, özellikle BDE kullanımında öğrencilere sağlanan görev odaklı teşviklerin daha etkili olduğu ve kullanıcılara sağlanan geri bildirim bilgilerinin yüzeysel olarak değil, zihinsel olarak işlenmesi gerektiği elde edilmiştir. Roblyer, Castine ve King [25] ise "Assessing the Impact of Computer-Based Instruction" (BDE’nin etkililiğinin değerlendirilmesi) isimli kitaplarında, BDE uygulamalarının belli kademe, öğrenci grubu ve derslerde en etkili kullanıldığ1 yolların incelenmesi gerektiğini belirtmiştir. BDE’nin öğrenme sürecine sağladığı katkıların yanı sıra, bazı dezavantajlarının da olduğu yapılan incelemelerden anlaşılmıştır. Bu noktada, özellikle kültürel farklılıklar veya davranışsal eğitim gibi 
öğrenci tutumlarını değiştirmeye çalışan programların öğretiminde, BDE gibi online uygulamaların pek etkili olmayacağı, bu tarz programlarda BDE'nin geleneksel yüzyüze eğitimi destekleme anlamında etkili bir şekilde kullanılabileceği belirtilmiştir [26]. Yine uluslararası nitelikteki bazı çalışmalarda BDE'ye ilişkin uygulamaların öğrenenlerin performansında olumsuz etki göstermemekle birlikte anlamlı bir fark da yaratmadığı ifade edilmiştir $[27,28]$. Bu nedenle, meta-tematik analiz yapılarak BDE konusundaki nitel araştırma sonuçlarının neler olduğu, öğrenme sürecindeki boyutlarının farklı açıları ele alınmak istenmiştir. Bu noktada, mevcut araştırmanın incelediği nitel çalışmalarla bu alana ayna tutacağı, alanyazını net bir şekilde yansıtarak BDE'nin çalışmalarda ulaşılan sonuçlarını farklı açılarıyla ortaya koyacağı beklenmektedir.

\section{Araștırmanın amacı ve önemi}

Teknolojik gelişmelere bağlı olarak eğitim alanında kullanılan yöntem ve tekniklerde de değişmeler meydana gelmeye başlamıştır. Bilgisayarın eğitim sürecine dâhil edilmesiyle öğrenme süreci daha verimli ve etkili olmaya başlamıştır. Özellikle bireyi merkeze alan eğitim faaliyetlerinde bilgisayarın, bireyin kendi öğrenme hızında ilerlemesine imkân sağladığı bilinmektedir. Bu anlamda, yakından uzağa ilkesi ve öğrenciye görelik ilkelerine göre bilgisayarın eğitim ortamına girmesiyle çocuğa yol gösterici rolünün ortaya çıktığı anlaşılmıştır [19]. Bu açıdan bakıldığında alanyazın taramalarında BDE'nin öğrencilerin başarılarını arttırmalarının yanında üst düzey düşünme becerilerini desteklediği ve ezberden ziyade kavrayarak öğrenmelerini sağladığı görülmüştür [29]. Ulusal alanyazında BDE'ye ilişkin yapılan nitel boyutlu çalışmaların etkililiği katılımcı görüşleri çerçevesinde ele alınmıştır [30, 31]. BDE ile ilgili yapılan meta analiz çalışmaları içerisinde ise yine bazı çalışmalarının ön planda olduğuna rastlanmıştır. Örneğin, Tabuk [32] bilgisayar destekli matematik eğitimi uygulamaları hakkında yapılan lisansüstü tezleri incelemiştir. Cristmann [33] meta analizden faydalanarak 24 tane çalışmayı bir araya getirdiği incelemesinde BDE'nin kırsal bölgelerde zayıf ancak şehirde daha verimli olduğu sonucuna ulaşmıştır. Batdı [34] BDE ile ilgili olarak yapmış olduğu meta analiz çalışmasında BDE'nin akademik başarıyı arttırdığını ortaya koymuştur. Bütün bu çalışmalar incelendiğinde, BDE'ye ilişskin yapılan çalışmaların meta analiz [35, 36] veya katılımc1 görüşüne dayalı nitel araştırmalar [37] olduğu kaydedilmiştir. $\mathrm{Bu}$ bakımdan, BDE ile ilgili alanyazında yapılmış nitel boyutlu çalışmaların meta-tematik analiz açısından incelenerek nitel çalışma bulgu ve sonuçlarının birleştirilmesi önemli görülmüştür. Dolayısıyla, BDE'nin etkililiğinin meta-tematik analiz çerçevesinde incelenmesi temel amacı bağlamında;

- BDE’nin akademik gelişime, tutuma ve teknolojiyi kullanma becerilerine etkisi ile

- BDE’nin sınırlılıklarına yönelik değerlendirmeler yapılmıştır.

\section{Yöntem}

\subsection{Araştırmanın türü ve deseni}

$\mathrm{Bu}$ araştırmada BDE'nin akademik gelişime, tutuma, teknolojiyi kullanmaya katkıları ile BDE'nin sınırlılıkları incelenmiştir. Yapılan incelemeler, nitel desende ve katılımcı görüşlerini içeren çalışmaların analizi ile gerçekleştirilmiştir. Bu amaçla, doküman 
incelemesine dayalı, metinsel içerikli çalışmalardan yeniden tema ve kodlar oluşturarak çalışmaların nitel bulgularını birleştiren bir analiz türü olan meta-tematik analizden faydalanılmıştır. Bu analiz türü ile belli bir araştırma konusunda nitel bağlamda gerçekleştirilmiş, doküman incelemesine dayalı elde edilen araştırmalardaki verilerin, ortak bir paydada toplanarak yeniden tema ve kodlar oluşturulması ve anlamlandırılması söz konusudur [38]. Meta-tematik analiz doğrudan katılımcı görüşlerine dayalı olarak gerçekleştirildiği için, geçerlik ve güvenirlik noktasında sağlam temellere dayandığ 1 belirtilebilir.

\subsection{Analize dâhil edilen çalışmalar}

Meta-tematik analiz kapsamında ulusal nitelikli Yükseköğretim Kurumu (YÖK) Tez Merkezi ve Google Akademik veri tabanlarından yapılan taramalar ile çalışmalara ulaşılmıştır. $\mathrm{Bu}$ amaçla "Bilgisayar temelli eğitim/öğretim, bilgisayar destekli eğitim/öğretim", anahtar kelimeleriyle yapılan taramalar sonucunda uygun tez ve makalelere ulaşılmaya çalışılmıştır. Bu aşamada, analiz için belli dâhil edilme kriterleri belirlenmiştir. Şekil 1'de bu kriterler ve analiz dışı gerekçeler görülmektedir. Moher ve ark. [39] geliştirmiş olduğu akış diyagramı (PRISMA) bu çalışmada meta-tematik analiz için uyarlanarak sunulmuştur.

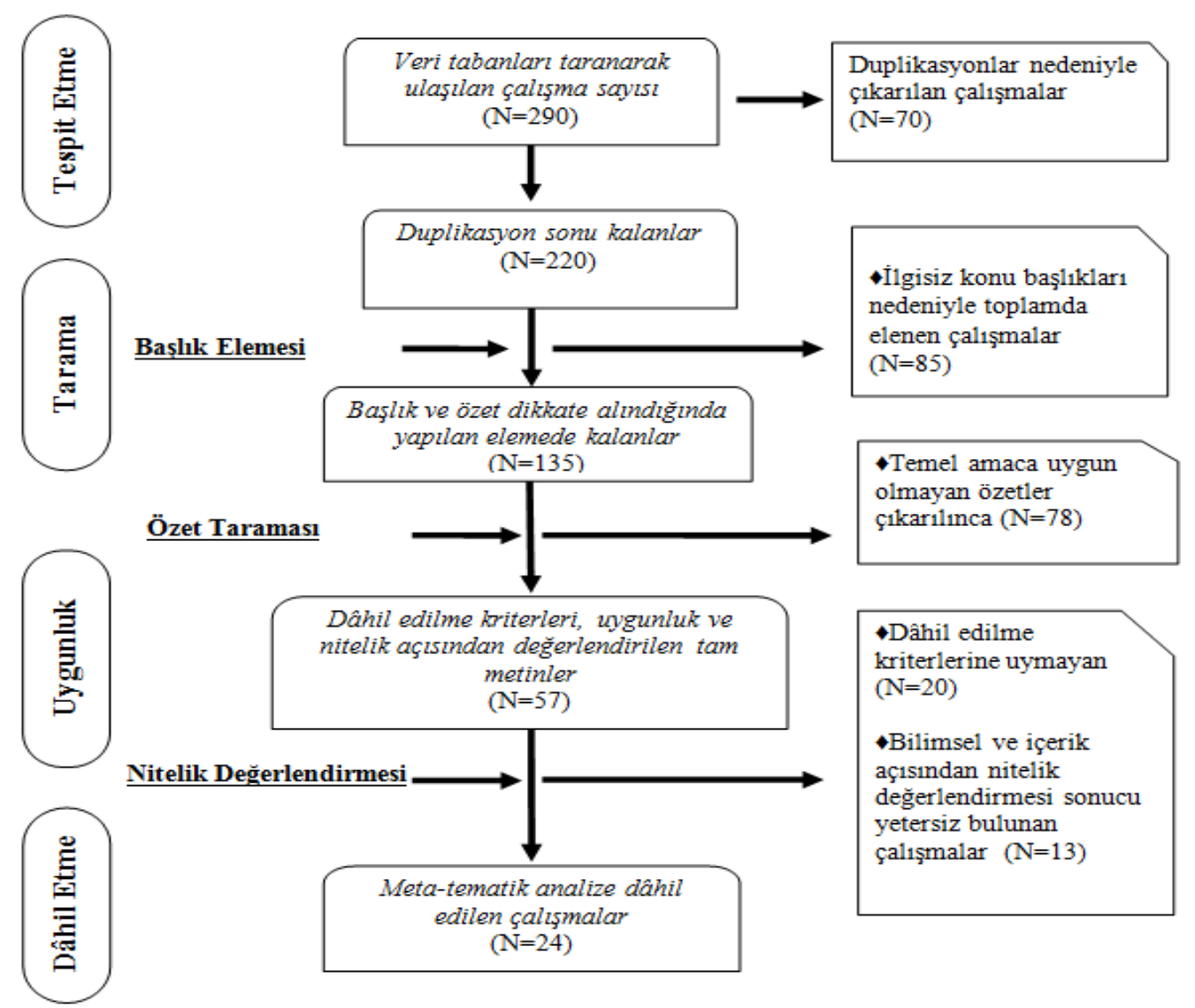

Şekil 1. Meta-tematik analize dâhil edilen çalışmaların akış diyagramı.

PRISMA diyagramı incelendiğinde, belirtilen 2 veri tabanından BDE'ye ilișkin 290 çalışmaya ulaşıldığı görülmüştür. Bu çalışmaların yayım yılları aralığı 2009-2020 olarak belirlenmiştir. Bu yıllar arasında ilgili konuya ilişkin ulaşılan 290 çalışmanın 70'i duplikasyon gerekçesiyle analiz dışı tutulmuştur. Duplikasyon, bir çalışmanın farklı veri tabanlarından erişilmesiyle birkaç kez indirilmiş olmasından kaynaklanmıştır. Bu 
çıkarımlar yapıldıktan sonra geriye 220 çalışma kalmıştır. Kalan çalışmaların 85'i başlık ve özetin içeriğine göre yapılan incelemede elenmiştir. Çünkü bu 85 çalışmanın başlık olarak uygun gibi görünüp içerik olarak araştırmanın temel amacıyla örtüşmediği görülmüştür. Tarama sonucu elde kalan 135 çalışmanın özetlerinin "uygunluk" kriteri açısından değerlendirilmesiyle amaca uygun olmayan 78'i daha çıkarılmıştır. $\mathrm{Bu}$ çalışmaların BDE'nin akademik gelişime, tutuma ve teknoloji kullanım becerilerine etkisiyle BDE'nin sınırlılıklarını içermeyen çalışmalar olduğu görülmüştür. Geriye 57 çalışma kalmıştır. Elde kalan çalışmaların, meta-tematik analiz için belirlenen dâhil edilme kriterleri doğrultusunda değerlendirilmesiyle 20'sinin katılımcıların görüşlerine yer vermediği, tarama/derleme tazında çalışmalar olduğu görülerek elenmesine karar verilmiştir. Kalan 37'sinin 13'ü içerik açısından ayrıntılı olarak incelendiğinde, yetersiz veri sunumu ve zayıf araştırma deseni gibi özellikler açısından bilimsel niteliği düşük olarak kabul edilmiştir. Bu sebeple analiz dişında tutulan 13 çalışmadan sonra araştırma dâhilinde 24 çalışma kalmıştır. Analize dâhil edilen bu çalışmalardan kod oluşturma sürecinde benzer tema ve kodları içeren çalışmalar analizden çıkarılmayıp, bu çalışmada sadece tema ve kodlarından yararlanılan çalışmalardan $(\mathrm{N}=8)[19,40,41,42,43,44,45$, 46] alıntılar yapılmıştır.

\subsection{Verilerin toplanması ve analizi}

Doküman incelemesinin yapıldığı bu çalışmalarda içerik analizinden faydalanılmıştır. Doküman incelemesi, araştırılması hedeflenen olgu veya olaylar hakkında bilgi içeren yazılı materyallerin analizini kapsamaktadır [47]. Doküman incelemesinde yazılı kaynaklar ele alınıp incelenmektedir. İçerik analizi, araştırmada incelenen verilerin tekrarlanabilir ve geçerli çıkarımlar yapmak amacıyla kullanıldığı bir araştırma yöntemi olarak açıklanabilir [48]. İçerik analizinde araştırmacı öncelikle kategorileri belirler, daha sonra bu kategoriler önceden elde edilmiş bilgi, kuram ve tecrübelere göre şekillendirilir [49].

Meta-tematik analiz aracılığıyla nitel boyutlu çalışmalardan elde edilen veriler tema ve kodlar şeklinde ifadelendirilmiştir. İlgili kodların oluşturulması bilgisayar programları aracılığıyla yapılabileceği gibi elle (manüel) de yapılabilmektedir [50]. Bu araştırmada kodlar elle oluşturularak görsel sunumu Wisemapping programıyla bilgisayarda yapılmıştır. Bu kodlar, akademik gelişim, tutum, teknolojiyi kullanma becerisi ve sınırlılıklar olarak 4 tema altında toplanmıştır. Ayrıca bu temalara yönelik iki veri kodlayıcısı arasındaki uyum hesaplanarak (Cohen Kappa uyum değerleri) uyumun iyi düzeyde olduğu görülmüştür. Bu arada analize dâhil edilen çalışmalardan, YÖK Tez Merkezi veri tabanından ulaşılmış tezler "T", numara ve kodun alındığı sayfa numarası verilerek kodlanmıştır (Örn: T6- s.64). Google akademik veri tabanında ulaşılan makaleler ise "M", numara ve kodun alındığı sayfa numarası ile kodlanmıştır (Örn: M1s.906). Çalışmaların kodlanmış şekli, bulguların yorumlanması sürecinde doğrudan alıntılar yapılırken verilmiştir. Güvenirlik noktasında yapılan alıntıların araştırmanın teyit edilebilirliğine katkı sunduğu [51] belirtilebilir.

\section{Bulgular}

Meta-tematik analiz bağlamında bu çalışmada elde edilen verilerin sunumu ve yorumlanması bu bölümde yapılmıştır. Ulaşılan temaların dört modelle görselleştirildiği görülmektedir (Şekil 2, 3, 4, 5). Bu tema başlıkları: BDE'nin akademik gelişime (Şekil 2), tutuma (Şekil 3), teknolojiyi kullanım becerilerine katkıları (Şekil 4) ile BDE'nin 
sınırlılıkları olarak belirtilebilir. Şekil 2'de sunulan görselde BDE'nin akademik gelişime etkisine yönelik kodların öğretmen ve öğrenci çerçevesinden değerlendirilerek iki alt tema şeklinde sunulduğu görülmektedir.

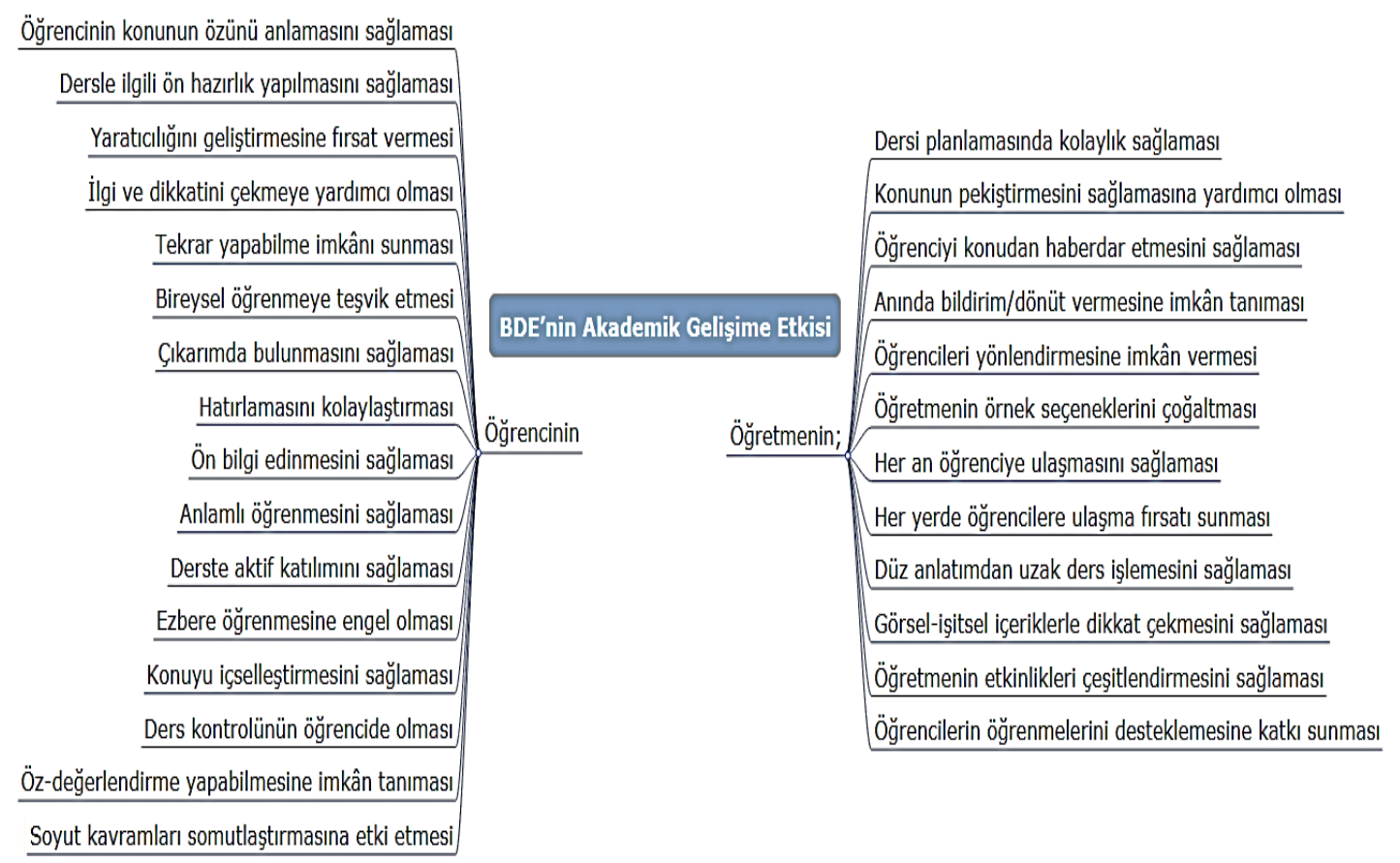

Şekil 2. BDE’nin akademik gelişime etkisi.

Şekil 2'de BDE'nin akademik gelişime etkisi teması altında öğretmen ve öğrenci açısından sıralanan kodlar olduğu görülmektedir. Öğretmen açısından oluşturulan kodlardan bazılarının "dersi planlamada kolaylık sağlaması, anında dönüt vermesine imkân tanıması, öğrencileri yönlendirmeye fırsat vermesi, her an ve her yerde öğrenciye ulaşma firsatı sunması" şeklinde belirtildiği görülmüştür. Bu noktada referans alınan ifadelerden bazıları M1- s. 906 kodlu çalışmada "Temel amacı yani ögrrenciye ögretmektir. Öğrenciyi derse katmak olabilir diye düşünüyorum.”, T1- s. 56 kodlu çalışmada "Kendimi yeterli buluyorum. Çocuklara ögretilecek kavramları sınıfta ögrettikten sonra, bilgisayardaki etkinliklerden yararlanarak onlarl destekliyorum..." T1-s. 57 kodlu çalışmada "Çocuklara ögrendiklerini pekiştirme firsatı sağlayabilir...", T2-s. 81kodlu çalışmada "Genelde birçok çocuk bilgisayarı sevdiğinden matematik gibi anlaşılması zor bir ders böylelikle daha ilgi çekici hâle geldi. Üç boyutlu cisimleri aklımızda canlandırmamı zor olduğu için anlamakta daha önce sıkıntı yaşıyorduk ama bilgisayar destekli ögretimde bu sıkıntı ortadan kalkmış oldu” biçimindedir. BDE'nin öğretmenlere sağladığı kolaylıklar kodlarda belirtildiği gibi öğrencinin dikkatini çeken ve farklı öğrenme faaliyetleri sunarak öğrenciyi derse odaklayan türdedir. Ayrıca öğretmenin her an ve her yerde öğrenciye ulaşabilmesi "öğretimin her yerde gerçekleştirilebilmesi"ne imkân vermektedir.

BDE'nin öğrencilerin akademik gelişimine etkisi bağlamında görseldeki kodlardan bazıları "bireysel öğrenmeye teşvik etmesi, yaratıcılığını geliştirmesine fırsat vermesi, hatırlamasını kolaylaştırması, ders kontrolünün öğrencide olması, ilgi ve dikkatini çekmeye yardımcı olması, öz-değerlendirme yapabilmesine imkân tanıması, tekrar yapabilme imkânı sunması" şeklinde belirtilmiştir. İlgili kodlar oluşturulurken, T7- s. 106 kodlu çalışmada "Etkinlikler için önceden biraz çalışmamı gerekiyordu, ben şiir 
yazarken mesela bunu arkadaşlarımın göreceğini tahmin etmedim. Gruba eklediğim zaman sınıf arkadaşlarımın tamamı gördü.", yine aynı çalışmadan "Elektronik ortamda ders yaptık, bu derslerde sinıftaki ortamdan farklı olarak bilgisayar bizim kontrolümüzdeydi. Etkinliklerde ile çeşitli grafikler oluşturduk biraz uğraşmak gerekti. Ama eğlenceliydi diyebilirim."; T5-s.121 kodlu çalışmada "Animasyonlu ders işlediğimizde animasyonlar aklımda kalıyor. Bu nedenle konuları kolay hatırlıyorum."; T4-s.66 kodlu çalışmada ise "Öğretmen her yaptı̆̆ımız soruya hemen doğru ya da yanlış diyemiyor ama bilgisayarda hemen söylüyor ve ipucu da veriyor." şeklindeki ifadelerden yararlanıldığı belirtilebilir. Bu kodlar ve alıntılar incelendiğinde, BDE'nin akademik açıdan öğrenciye birçok alternatif sunarak her yerde öğrenebilme ve kendi düzeyi, hızı ve ilgi alanı doğrultusunda ilerleyebilme imkânları sunduğu anlaşılmaktadır. Öğrenciye düz anlatım, sunu gibi geleneksel öğrenme yaklaşımlarında ulaşamayacağı firsatlar sunması, öğrenilenleri pekiştirmesi, yeni öğrenmeleri desteklemesi öğrenciyi eğitim sürecinde aktif kılmaktadır. Bundan dolayı BDE'nin akademik gelişime katkılarının yadsınamayacak düzeyde olduğu düşünülmektedir. BDE'nin öğrencilerin duyuşsal özellikleri ve derse karşı tutumlarıyla ilgili de etkisine değinilmiştir. Şekil 3’ü inceleyelim.

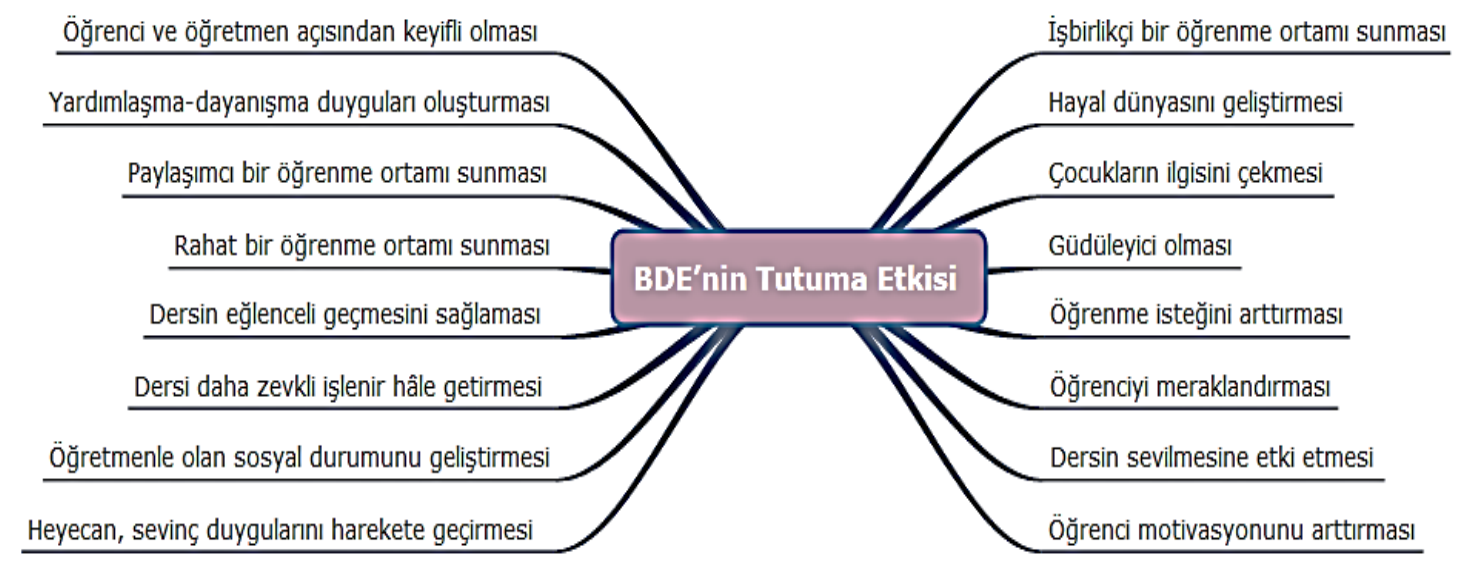

Şekil 3. BDE'nin tutuma etkisi.

Şekil 3'te BDE'nin öğrencilerin derse karşı tutumları açısından ulaşılan kodlar olduğu görülmektedir. Bu kodlardan bazıları "dersi daha zevkli işlenir hâle getirmesi, çocukların ilgisini çekmesi, öğrenci motivasyonunu arttırması, işbirlikçi bir öğrenme ortamı sunması, heyecan, sevinç duygularını harekete geçirmesi” şeklinde sunulmuştur. Bu kodların referans aldığı ifadeler T3- S. 169 kodlu çalışmada "Türkçe dersini bilgisayarla geçirmek daha zevkli ve T1-s. 53 "Bilgisayar kullanmak çocuğun oldukça ilgisini ve dikkatini çeken, derse yönelmesini sağlayan bir kullanımdır...” T1- s. 91 kodlu çalışmada “...gerekli olduğunu düşünüyorum. Ögrencinin motivasyonunu arttırır...”, T7- s. 108'de "Ben pek fazla bir şey paylaşmadım. Sınıfta sadece internet ortamında grup çalışmasını sanal bir şekilde yaptık." şeklinde belirtilebilir. İlgili kodlar ve alıntılar, BDE'nin derse yönelik iyi duygular beslemeyi, ders esnasında mutlu ve istekli olmayı, dersi sevmeyi sağlayarak öğrencilerin 'ders ve öğrenme süreci' konusundaki algılarını değiştirdiği belirtilebilir. Bunun yanı sıra, BDE’nin, teknolojik becerileri geliştirmede de katkısı olduğu görülmektedir. Şekil 4'te bu katkıları model halinde görmek mümkündür. 


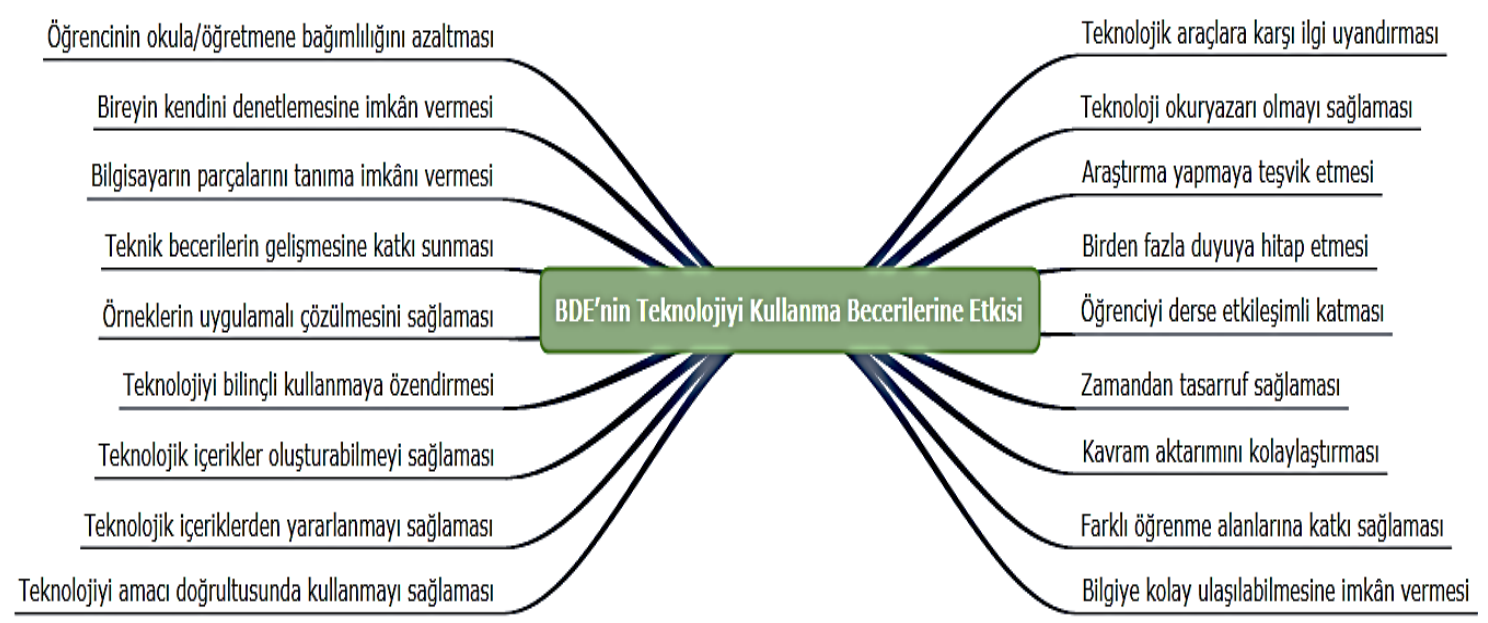

Şekil 4. BDE'nin teknolojiyi kullanma becerilerine etkisi.

Şekil 4'te BDE'nin teknolojiyi kullanma becerilerine etkisine ilişkin kodların sıralandığ görülmektedir. "Zaman tasarrufu sağlaması, birden fazla duyuya hitap etmesi, teknolojiyi amac1/ihtiyacı doğrultusunda kullanmayı sağlaması, teknolojik içerikler oluşturabilmeyi sağlaması, teknolojik araçlara karşı ilgi uyandırması, teknik becerilerin gelişmesine katkı sunması, teknoloji okuryazarı olmayı sağlaması, teknolojik içerikler oluşturabilmeyi sağlaması" ilgili kodlardan bazılarıdır. Belirtilen kodların alıntılandığı çalışmalardan bazı örnek ifadeler "Zamandan kazanç sağlanır. Çünkü şu anki eğitimde tahta kullanılıyor, bunu da büyük bir zaman kaybl olarak düşünüyorum." (M1-s. 905), "...çocukların birçok duyu organına hitap ettiği için öğrenmelerinde faydalı olur." (T1- s.56), "Günlük, aylık, yıllık planlar çıkarma ve farklı etkinlikler bulma açısından bilgisayar kullanımı önemli bir yer tutmaktadır.” (T1-s. 53), “... Öğrenciye hangi örnekle ne şekilde etkili olabilir diye. Tabi en etkili örnekler bulmamız ve hazırlamamız gerekir. Bunu görsel olarak da aktarabildiğimiz zaman çok da mükemmel bir eğitim olur." (M1s. 908), “.. Bilgisayar görsel ve işitsel öğeler barındırması gibi özellikleriyle daha öğretici ve açıklayıcı oluyor." (T2- s. 87), "Bilgisayarlardan daha kolay ve farklı kaynaklara ulaşıp, güzel etkinlikler bulabiliriz... bilgiye kolay erişilebilir” (T1-s. 55), M1- s.906 kodlu çalışmada "Öğrenci açısından dersi daha zevkli işlenir hale getirmek olabilir. Öğrencinin görselliğine hitap etmek, benim amacım o olur. Yani ögrenciye görsel olarak aktarabilmek...”, şeklinde belirtilebilir. BDE'nin hem öğretmen hem de öğrencilerin teknolojiyi bilinçli, amaç ve ihtiyaçlar doğrultusunda kullanma alışkanlığı edinmelerine imkân verdiği anlaşılmaktadır. Öğretmenlerin bu içerikleri öğrencilerle paylaşmalarının ve öğrencilerin de süreci kontrollü bir şekilde takip edebilmelerinin her ikisinin de teknolojiyi gelişimleri doğrultusunda kullandıkları şeklinde yorumlanabilmektedir. Özellikle zamandan bağımsız davranabilme öğrenme sürecinde esneklik sağlayarak daha verimli ve etkili bir süreç oluşmasına imkân vermektedir.

Şekil 5 incelendiğinde BDE'nin sınırlılıklarına değinen bazı kodlarla karşılaşılmaktadır. Bu kodlar "teknik sorunların yaşanması, zaman kaybına yol açması, dikkat dağınıklığına sebep olması, sosyalleşmeyi azaltması, bilgisayar kullanımının bilinmemesi, bilgisayarın ders dışında kullanılması" şeklinde belirtilmiştir. 


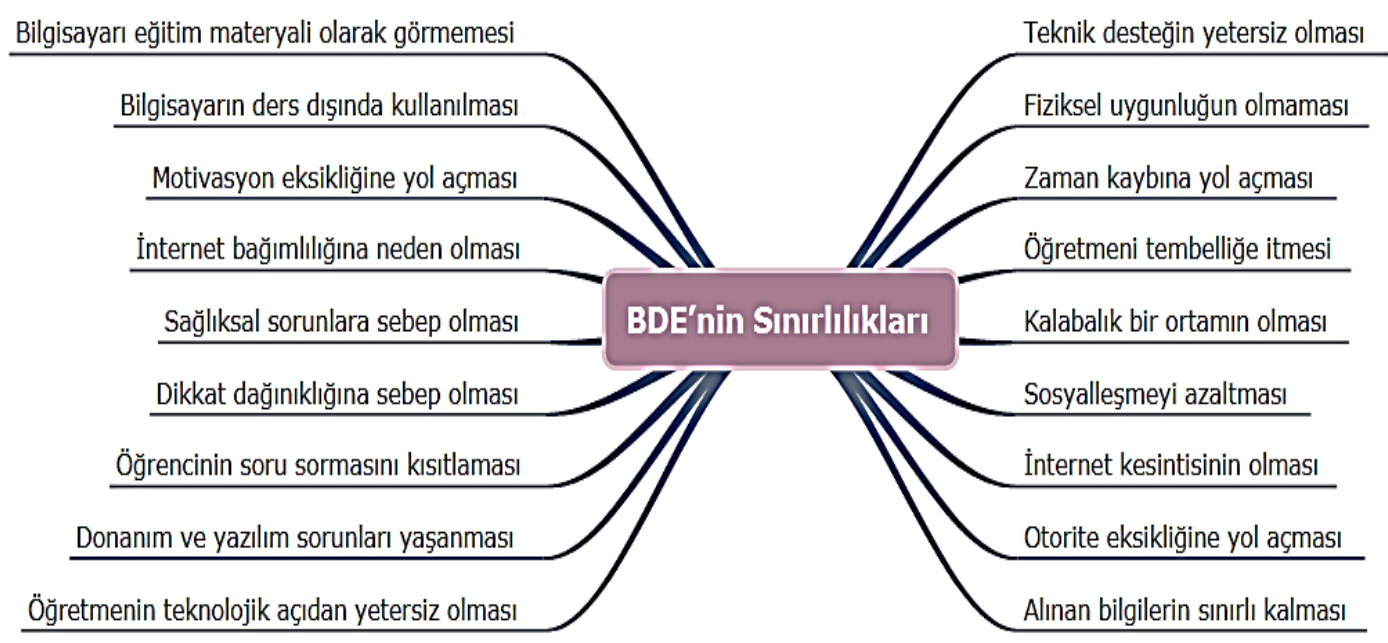

Şekil 5.BDE’nin sınırlılıkları.

İlgili kodların oluşturulmasında T2- s.95 kodlu çalışmadan "Zaman zaman bazı teknik sorunlar yaşandı. İnternet bağlantısı yavaştı veya hiç yoktu. Bu durumlarda dersimiz aksadı. Bunun dişında bazı arkadaşlarımız bilgisayarı bir oyun aracı olarak gördükleri için dersi ciddiye almadılar.", T1-s. 55 kodlu çalışmadan "Kullanımı konusunda belirli basit düzeyde şeyleri biliyorum. Yeterli tecrübe ile kendimi geliştirmem gerek...”, M1-s. 905 kodlu çalışmadan alıntılanan "...tabii ki olumsuz yanları. en basitinden zaman kaybıdır öğretici için ve ögrenci için de bu." Ve T4- s.74 kodlu çalışmadan "Bireysel olduğu için sosyalleşme yok, öğretmen-öğrenci ya da öğrenci-öğrenci arasında bilgi alışverişi mümkün değil." şeklinde alınan ifadelerden faydalanıldığı belirtilebilir. Bu ifadelerden yola çıkarak BDE'nin teknik yönlerden, öğretmenin yeteri kadar bilgisayar kullanmayı bilmemesi, öğrencilerin bilgisayarı bir oyun olarak görmesi ve BDE sunulurken internet bağlantısının kesilmesi gibi olumsuz etkileri olduğu belirtilebilir. Daha planlı ve bilinçli bilgisayar kullanımı ile bu sorunların üstesinden gelinebileceği düşünülmektedir.

\section{Tartışma ve sonuç}

Meta-tematik analize bağlı olarak yapılan bu araştırmada BDE'nin öğrenme sürecindeki etkisi belirlenmeye çalışılmıştır. Yapılan değerlendirmelerde, ulaşılan çalışmalardan elde edilen verilere göre, BDE'nin akademik gelişim, tutum ve teknolojiyi kullanma becerileri noktalarındaki katkısı ile sınırlılıklarına ilişkin kodlar elde edildiği görülmüştür. Analiz sonuçları BDE'nin birçok açıdan öğrenme sürecinde pozitif etkileri olduğunu göstermiştir.

Eğitim materyali olarak kullanılan bilgisayarın öğrenci ve öğretmen üzerinde pek çok etkisi bulunmaktadır. Öğrencinin derse olan ilgisini arttırarak aktif katılımını sağlaması ve konuları zorluk çekmeden eğlenerek öğretmesine etki etmesi BDE'nin en belirgin özellikleri arasında sayılabilir. Mevcut araştırmada, meta-tematik analiz ile ulaşılan kodlar arasında BDE'nin öğretmen ve öğrenciler açısından sunduğu yararlar ayrı olarak belirtilmiştir. Hem öğretmen hem de öğrencinin daha rahat ve ulaşılabilir içerik sağladığ 1 sonuçlardan anlaşılmaktadır. Alanyazında da Dikmen ve Tuncer [52] meta-analiz yöntemini kullanarak 2007-2017 yılları arasında yapılmış olan BDE ile ilgili yapılmış olan tezleri incelemiş ve her geçen yıl BDE'nin akademik başarıya etkisinin daha fazla 
olduğu sonucuna ulaşmıştır. Teyfur [43], "9. Sınıf Coğrafya Dersinde Bilgisayar Destekli Öğretimin Öğrenci Başarısı ve Tutumuna Etkisi” adlı çalışmasında BDE'nin eğitim sürecine katkılarını ortaya koymuştur. Bunun yanı sıra çocuklara ulaşamayacağı firsatlar sunma, düz anlatımdan uzak ders işleme ve anlatımı kolaylaştırma BDE'nin diğer önemli işlevleri arasında sayılmaktadır. Bilgisayar yoluyla sunulan ders içeriklerinin anlatımı düzlükten kurtararak daha ilgi çekici hâle getirdiği anlaşılmıştır. Ayrıca çocukların seviyelerine uygun olarak hazırlanmış yazılımların hem öğretmenin ders anlatma sürecini kolaylaştırmakta hem de öğrencilerin dikkatini çekmekte olduğu vurgulanmıştır. Bu sonuçlar, bilgisayarların eğitim sürecinde pekiştirmeyi sağlayan araçlar olduğu düşüncesini desteklemektedir.

Modern çağda bilgisayar yoluyla yapılan eğitim dünyanın birçok yerinde uygulama aşamasındadır. Bu süreçte öğrenilen bilgilerin pratiğe dökülmesi ve bir sonraki aşamaya geçilmesinde de BDE dikkat çekmektedir [53]. Yapılan mevcut çalışmada da BDE'nin akademik gelişime büyük katkıları olduğu görülmüştür. Bu noktada Durukan'ın [45] çalışmasında BDE'nin Dilbilgisi öğretiminde başarı ve tutuma etkisinin incelendiği kaydedilmiştir. BDE'nin başarı açısından anlamlı öğrenmeler sağladığı görülmüştür. Özcan'ın [44] Türkçe dersinde kullandığı animasyon destekli 5E modeline ilişkin çalışmasında, bilgisayar uygulamalarının kalıcı öğrenmeler sağlandığı belirtilmişstir. Bu sonuçlar, mevcut araştırma sonucumuza benzer şekilde BDE ile çocukların kalıcı öğrenmelerinin arttığını ve yeni öğrenmelerinin pekiştirildiğini göstermektedir. Alanyazında buna benzer başka çalışmalarla $[13,54]$ karşılaşılması mevcut sonucu kuvvetlendirmektedir.

BDE'nin tutuma olan etkisi de sorgulanan diğer bir boyuttur. Bu kapsamda, BDE'nin motivasyonu arttırma, derse karşı ilgiyi destekleme, merak unsurunu arttırma ve dersten haz alma gibi etkilerinin göze çarptığı söylenebilir. Aynı konuda yürütülmüş çalışmalara bakıldığında, Özcan'ın [44] Türkçe dersinde bilgisayarlı uygulama sonucunda, öğrencilerin derse olan ilgilerinin arttığı, motivasyonun sağlandığı ve dersin daha çok sevildiği gibi tutuma ilişkin veriler elde ettiği görülmüştür. Yine benzer şekilde, Ovalı'nın [19] çalışmasında dersten zevk alma, eğlenerek öğrenme, dersi sevme, motivasyon gibi tutumla ilgili sonuçlara ulaşıldığı tespit edilmiştir. Benzer sonuçların ulusal olduğu gibi $[46,55]$ uluslararası alanyazınla da desteklendiğine ilişkin örnek çalışmalara [56, 57] rastlanmıştır. BDE'nin tutum noktasındaki etkililiği hususunda, öğretmenlerin istekli ve ilgili olmalarının ayrıca önemli olduğu ve BDE'nin verimlilik düzeyinin bu istek oranında artabileceği vurgulanmıştır [58]. Bu durumda öğretmenlerin BDE’yi kullanmaya yönelik tutumlarının öğrencileri de etkilediği söylenebilir.

BDE'nin teknolojiyi kullanma becerilerine de etkisinin olduğu dikkat çekmiştir. Bu noktada, bilgisayar kullanımından dolayı, teknolojiyi daha bilinçli kullanabilme, otokontrol becerisiyle hareket edebilme, teknolojik içerikler hazırlayabilme ve bunlardan faydalanabilme gibi özelliklerin geliştiğine dikkat çekilmiştir. Bilgisayarların teknik bilgi ve becerilerin gelişimde etkili olduğu ve bu becerilerin araştırma yapma becerilerini olumlu yönde etkilediği belirtilebilir. Özellikle zaman tasarrufu sağladığı ve kavram aktarımını kolaylaştırdığı için, bu becerileri farklı ders ve öğrenme alanlarında (ilgi alanına göre sanat, spor, müzik, yemek, vb.) da kullanabilmektedir. Benzer sonuçlara alanyazında yürütülmüş bazı çalışmalarda da rastlanmıştır. Yıldırım ve Kaban [59], BDE’nin öğrenme hızını belirleme, etkileşimli öğrenme, öğretimsel yazılım kullanma ve zaman tasarrufu açısından birçok faydası olduğunu belirtmiştir. Adıgüzel ve Berk [60] öğretme-öğrenme sürecinde bilgisayar gibi öğretim teknolojileri kullanımının 
yaygınlaştıkça, ülkenin teknoloji okuryazarlık düzeyinin de yükseleceğini ve böylece bilgi çağına ulaşmış bir toplum olacağını belirtmiştir.

BDE'nin olumlu yanlarının yanı sıra olumsuz yönleri de vardır. Eğitim sürecinde kullanılan materyalin elektronik olması bir takım sıkıntıları beraberinde getirebilmektedir. Bilgisayarın bir eğitim materyali yerine bir oyun aracı olarak algılanması ise ayrı bir bakış açısıdır. BDE'de kullanılan yazılımın yetersiz olması, öğretmenin bilgisayar kullanmadaki tecrübesizliği bu süreci olumsuz etkileyebilmektedir. Alanyazına bakıldığında öğretmen tutumlarıyla ilgili olumsuz görüşlere Aydoğdu'nun [61] çalışmasında ulaşılmıştır. Ayrıca yeterli donanıma sahip olan bazı okullarda da yine öğretmenlerin çok tercih etmedikleri [62], BDE'nin bilgisayar veya oyun bağımlılı̆̆ 1 yapabildiği [63], eleştirel düşünme ve analiz becerilerini negatif yönde etkileyebildiği [64] gibi bazı sonuçlarla da alanyazında karşılaşılmaktadır. Ancak gerekli planlamalar ve düzenlemeler yapıldığında, bilgisayar kullanım saatleri ayarlandığında ve bilinçli kullanım alışkanlığı edinildiğinde, BDE’nin olumsuz yönlerinin azalacağı düşünülmektedir.

Bu çalışmada BDE’yi bilgisayarı bir öğrenme materyali olarak kullanmamızı sağlayan BDE'nin akademik, tutum, teknolojik becerileri ve sınırlılıklar de ele alınmıştır. Sağladığı katkılar düşünüldügünde, zaman ve mekân sınırı olmadan öğrenme ve ilgi çekici içeriklerle öğrencilerin dikkatini çekebilme gibi özellikleri ile tercih edilmesi gereken bir yöntem olduğu belirtilebilir. Okul öncesi dönemde sayı ve şekil kavramlarını geliştirme; ilkokul döneminde okuma becerilerini destekleme; ortaokul ve lise düzeyinde ise ders bazında akademik açıdan pozitif katkılar sunma noktalarındaki etkililiği dikkat çekmiştir. Ayrıca üniversite düzeyinde mesleki alan konusunda içerdiği grafik, animsyon, video ve ses kayıtları gibi araçlarla ve sunduğu uzaktan eğitim imkânları kapsamında hazırlanan sunular aracılığıyla sesli, hareketli ve görüntülü dersler sayesinde bireylerin etkili ve kalıcı öğrenme, alanlarında iyi düzeyde yetiştirilebilme, ve teknolojik yeterliklerini arttırabilme açılarından olumlu yönlerinin belirtildiği görülmüştür. $\mathrm{Bu}$ açıdan ülke olarak daha dikkatli ve bilinçli kullanıcılar gibi davranarak BDE'nin sunduğu imkânlardan yararlanmalıyız. Diğer yandan alanyazında bu alanda yapılmış olan çalışmaların daha çok nicel yönlü olduğu dikkat çekmiştir. Bu çalışmanın nitel veriler çevresinde gerçekleştirilmesi ve bireylerin konuyla ilgili görüşlerine ulaşılması bu noktada çalışmanın önemini arttırmaktadır. Özellikle bu durum meta-tematik analiz çalışmalarının önemini ortaya koymaktadır. Bu sebeple BDE'nin farklı boyutlarıyla ilgili yapılacak olan çalışmaların meta-tematik analiz çerçevesinde incelenmesi önerilmektedir.

\section{Kaynaklar}

(* Analize Dâhil Edilen Kaynaklar)

[1] Bayraktar, B., Tapan Broutin, M.S. ve Güneş, H., Cabri 3D kullanımının öğretmen adaylarının analitik geometri dersi başarılarına etkisinin incelenmesi, Academy Journal of Educational Sciences, 2(2), 172-192, (2018).

[2] Vernadakis, N., Avgerinos, A., Tsitskari, E. ve Zachopoulou, E., The use of computer assisted instruction in preschool education: making teaching meaningful, Early Childhood Education Journal, 33(2), 99-104. (2005).

[3] Kesicioğlu, O. S., Doğrudan öğretim yöntemiyle hazırlanan eğitim programının ve bu yönteme göre hazırlanan bilgisayar destekli eğitim programının okul öncesi 
çocuklarının geometrik şekil kavramlarını öğrenmelerine etkisinin incelenmesi, Yayımlanmamış Doktora Tezi, Gazi Üniversitesi Eğitim Bilimleri Enstitüsü, Ankara, (2011).

[4] Kaçar, A.Ö. ve Doğan, N., Okul öncesi eğitimde bilgisayar destekli eğitimin rolü, Akademik Bilişim, 31, 1-11. (2007).

[5] Tosun, N., Bilgisayar destekli ve bilgisayar temelli öğretim yöntemlerinin, öğrencilerin bilgisayar dersi başarısı ve bilgisayar kullanım tutumlarına etkisi: "Trakya üniversitesi eğitim fakültesi örneği, Yayımlanmamış Doktora Tezi, Trakya Üniversitesi Fen Bilimleri Enstitüsü, Edirne, (2006).

[6] Varol, N., Bilgisayar destekli eğitim, Türk Cumhuriyeti ve Asya Pasifik Ülkeleri Uluslararası Eğitim Sempozyumu, Elazığ, 138-145, (1997).

[7] Çeliköz, N. ve Kol, S., Bilgisayar destekli öğretimin (BDÖ) altı yaş çocuklarına zaman ve mekân kavramlarını kazandırmaya etkisi, Kastamonu Eğitim Dergisi, 24 (4), 1803-1820, (2016).

[8] Okur, A. N. ve Halmatov, M., Okulöncesi öğretmen adaylarının bilgisayar destekli eğitim yapmaya ilişkin tutumlarının incelenmesi, Trakya Üniversitesi Eğitim Fakültesi Dergisi, 5 (1), 44-50, (2015).

[9] Schweinhart, L.J., Günümüzde erken çocukluk eğitimi ve müfredat modelleri, Ebru Aktan Acar (Ed.), Erken Çocukluk Eğitimi Mozaiği içinde (ss.1-11), Ankara: Nobel akademik yayınc1lik, (2017).

[10] Gündoğan, A., Okul öncesi dönemde bilgisayar destekli eğitim projeleri, Gazi Eğitim Fakültesi Dergisi, 34(3), 437-449, (2014).

[11] Çoruh, L., Bilgisayar Destekli Eğitim kapsamında hazırlanan bilgisayar oyunlarının 4-6 yaş arası çocuklara temel kavramların öğretilmesindeki etkisi, Yayımlanmamış Yüksek Lisans Tezi, Gazi Üniversitesi Eğitim Bilimleri Enstitüsü, Ankara, (2004).

[12] Atalay, Y., Okul öncesi öğretmenlerinin bilgisayar destekli eğitime ilişkin tutumları, bilgisayar kullanma yeterlilikleri ve bilgisayar kullanma sıklıklarını etkileyen faktörlerin incelenmesi, Yayımlanmamış Yüksek Lisans Tezi, Çanakkale 18 Mart Üniversitesi Eğitim Bilimleri Enstitüsü, Çanakkale, (2016).

[13] Kaçar, A.Ö., Okulöncesi eğitimde bilgisayar destekli eğitimin önemi, Yayımlanmamış Yüksek Lisans Tezi, Gazi Üniversitesi Fen Bilimleri Enstitüsü, Ankara, (2006).

[14] Karabulutlu, L., Okul öncesi fen eğitiminde analojilerin ve bilgisayar destekli eğitimin akademik başarı açısından değerlendirilmesi, Yayımlanmamış Yüksek Lisans Tezi, Kafkas Üniversitesi Fen Bilimleri Enstitüsü, Kars, (2018).

[15] Gürol, A. ve Yıldız, E., İlk okuma yazma öğretiminde bilgisayar destekli eğitimin ilkokul birinci sınıf öğrencilerinin ilk okuma yazma becerilerine etkisi, International Journal of Field Education, 1 (1), 1-18, (2015).

[16] Kaplan, A., Öztürk, M., Altaylı, D. ve Ertör, E., Sınıf öğretmenlerinin bilgisayar destekli öğretime yönelik tutumlarının bazı değişkenlere göre karşılaştırılması, Turkish Journal of Computer and Mathematics Education, 4 (2), 89-103, (2013).

[17] Engin, A.O., Tösten, R. ve Kaya, M.D., Bilgisayar destekli eğitim, Sosyal Bilimler Enstitüsü Dergisi, 5, 69-80, (2010).

[18] Aladă̆, U. İlk okuma yazma öğretiminde bilgisayar destekli öğretim yöntemine ilişkin öğretmen görüşlerinin incelenmesi (Ağrı ili örneği), Yayımlanmamış Yüksek Lisans Tezi, Erzincan Üniversitesi Sosyal Bilimler Enstitüsü, Erzincan, (2012). 
[19] *Ovalı, T., İlköğretim sekizinci sınıf Türkçe dersinde bilgisayar destekli öğretimin öğrencilerin anlama becerisine etkisi, Yayımlanmamış Yüksek Lisans Tezi, Sakarya Üniversitesi Eğitim Bilimleri Enstitüsü, Sakarya, (2011).

[20] Şen, Ü. S., Müzik öğretiminde bilgisayar destekli programlı öğretim yönteminin etkililiği, Yayımlanmamış Doktora Tezi, Gazi Üniversitesi Eğitim Bilimleri Enstitüsü, Ankara, (2011).

[21] Sakallı, A.N., Bilgisayar destekli proje tabanlı öğretim yaklaşımına göre hazırlanmış bir dersin öğrencilerin ders başarılarına ve tutumlarına etkisinin belirlenmesi ve öğrenci görüşlerine yansıması (Matematik dersi örneği), Yayımlanmamış Yüksek Lisans Tezi, Gazi Üniversitesi Eğitim Bilimleri Enstitüsü, Ankara, (2013).

[22] Çevik, E., Bilgisayar destekli kimya eğitimi ile ilgili öğretmen ve öğrenci görüşleri, Yayımlanmamış Yüksek Lisans Tezi, Hacettepe Üniversitesi Fen Bilimleri Enstitüsü, Ankara, (2006).

[23] Kulik, C. L. C. ve Kulik, J. A., Effectiveness of computer-based instruction: an updated analysis, Computers in Human Behavior, 7, 75-94, (1991).

[24] Morrison, G. R., Ross, S. M., Gopalakrishnan, M., ve Casey, J., The effects of feedback and incentives on achievement in computer-based instruction, Contemporary Educational Psychology, 20(1), 32-50, (1995).

[25] Roblyer, M. D., Castine, W., \& King, F. J., Assessing the impact of computerbased instruction: A review of recent research, The Haworth Press: NY, (1988).

[26] Taylor, R. W. (2002). Pros and cons of online learning - a faculty perspective. Pros and cons of online learning - a faculty perspective. Journal of European Industrial Training, 26(1), 24-37. doi: doi.org/10.1108/03090590210415876

[27] Lane, A. \& Porch, M. (2002) Computer Aided Learning (CAL) and its impact on the performance of nonspecialist accounting undergraduates, Accounting Education: An International Journal, 11(3), 217 -233.

[28] Sangster, A. (1992) Computer-based instruction in accounting education. Accounting Education: An International Journal, 1(1), 12-32.

[29] Renshaw, C. E, ve Taylor, H. A., The educational effectiveness of computer-based instruction, Computers and Geosciences, 26(6), 677-682, (2000).

[30] Aktepe, V. (2011). Sınıf öğretmenlerinin derslerinde bilgisayarı kullanımlarına ilişkin görüşleri. Ahi Evran Üniversitesi Eğitim Fakültesi Dergisi, 12(3), 7592.

[31] Yıldız, E. (2020). Çevrimiçi öğrenme ortamlarında uzaktan eğitim öğrencilerinin topluluk hissine etki eden faktörlerin incelenmesi. Eğitimde Nitel Araştırmalar Dergisi/ENAD- Journal of Qualitative Research in Education, 8(1), 180-205. doi:10.14689/issn.2148-2624.1.8c.1s.9m

[32] Tabuk, M., Lisansüstü tezlerde bilgisayar destekli matematik öğretimi uygulamaları: meta- sentez çalışması, Kuramsal Eğitimbilim Dergisi, 12(2), 656-677, (2019).

[33] Christmann, E.P., A meta-analysis of the effect of computer-assisted instruction on the academic achievement of students in grades 6 through 12: A comparison of 127 urban, suburban, and rural educational settings, Unpublished Doctoral Dissertation, Old Dominion University, Norfolk, VA, (1995).

[34] Batd1, V., A meta-analytic study concerning the effect of computer based teaching on academic success in Turkey, Educational Sciences: Theory \& Practice, 15(5), 1-16, (2015). 
[35] Camnalbur, M. (2008). Bilgisayar destekli öğretimin etkililiği üzerine bir meta analiz çalışması., Yayınlanmamış Yüksek Lisans Tezi, Marmara Üniversitesi Eğitim Bilimleri Enstitüsü, İstanbul.

[36] Dikmen, M., \& Tuncer, M. (2018). Bilgisayar destekli eğitimin öğrencilerin akademik başarıları üzerindeki etkisinin meta-analizi: son 10 yılda yapılan çalışmaların incelenmesi. Turkish Journal of Computer and Mathematics Education, 9(1), 97-121.

[37] Gürbüz, T., Yıldırım, S., \& Özden, M. Y. (2001). Öğretmen adaylarının çevrimiçi ve geleneksel bilgisayar okuryazarlığ derslerinde bilgisayara yönelik tutumlarının karşılaştırılması: Bir durum çalışması. Eğitim ve Bilim, 26(119), 4956.

[38] Batd1, V., Meta-tematik analiz, V. Batd1 (Ed.), Meta-tematik analiz: örnek uygulamalar içinde, (ss. 10-76), Ankara: Anı Yayıncılık, (2019).

[39] Moher, D., Liberati, A., Tetzlaff, J., ve Altman, D. G., Preferred reporting items for systematic reviews and meta-analyses: the PRISMA statement. Annals of Internal Medicine, 151(4), 264-269, (2009).

[40] *Akalan, M. E., Bilgisayar destekli programlı öğretim yaklaşımına gore hazırlanmış öğretim teknolojileri ve material geliştirme dersinin öğrencilerin akademik başarısına etkisi ve öğrenci görüşleri, Yayımlanmamış Yüksek Lisans Tezi, Gazi Üniversitesi Eğitim Bilimleri Enstitüsü, Ankara, (2012).

[41] *Hangül, T., Bilgisayar destekli öğretimin (BDÖ) 8. sınıf matematik öğretiminde öğrenci tutumuna etkisi ve BDÖ hakkında öğrenci görüşleri, Yayımlanmamış Yüksek Lisans Tezi, Balıkesir Üniversitesi Fen Bilimleri Enstitüsü, Balıkesir, (2010).

[42] *Kağızmanlı, B. ve Tatar, E., Matematik öğretmeni adaylarının bilgisayar destekli öğretim hakkındaki görüşleri: Türevin uygulamaları örneği, Kastamonu Eğitim Dergisi, 20(3), 897-912, (2012).

[43] *Teyfur, E., 9. Sınıf coğrafya dersinde bilgisayar destekli öğretimin öğrenci başarısı ve tutumuna etkisi, Yayımlanmamış Doktora Tezi, Dokuz Eylül Üniversitesi Eğitim Bilimleri Enstitüsü, İzmir, (2009).

[44] *Özcan, M. F., 7. sınıf Türkçe dersi "bildirme ve dilek kipleri" konusunun öğretiminde animasyon destekli 5e modelinin başarı, kalıcılık ve tutuma etkisi, Yayımlanmamış Doktora Tezi, Atatürk Üniversitesi Eğitim Bilimler Enstitüsü, Erzurum, (2015).

[45] *Durukan, E., İlköğretim 6. sınıfta bilgisayar destekli dil bilgisi öğretiminin başarı ve tutuma etkisi, Yayımlanmamış Doktora Tezi, Atatürk Üniversitesi Eğitim Bilimleri Enstitüsü, Erzurum, (2011).

[46] *Yenilmez, K., Öğretmen adaylarının bilgisayar destekli matematik öğretimi dersine yönelik görüşleri, Manas Üniversitesi Sosyal Bilimler Dergisi, 21, 207 220, (2009).

[47] Yıldırım, A. ve Şimşek, H., Sosyal Bilimlerde Nitel Araştırma Yöntemleri, Ankara: Seçkin Yayıncılık, (2013).

[48] Krippendorff, K., Content analysis: An introduction to its methodology, Thousand Oaks, CA: Sage, (2004).

[49] Büyüköztürk, Ş., Kılıç Çakmak, E., Akgün, Ö. E., Karadeniz, Ş. ve Demirel, F., Bilimsel Araştırma Yöntemleri, Ankara: Pegem Akademi, (2018).

[50] Merriam, S., Qualitative research: a guide to design and implementation (Third edition), San Fransisco, CA: Jossey Bass, (2009).

[51] Shenton, A. K., Strategies for ensuring trustworthiness in qualitative research projects, Education for information, 22(2), 63-75, (2004). 
[52] Dikmen, M. ve Tuncer, M., Bilgisayar destekli eğitimin öğrencilerin akademik başarıları üzerindeki etkisinin meta-analizi: Son 10 yılda yapılan çalışmaların incelenmesi, Turkish Journal of Computer and Mathematics Education, 9(1), 97-121, (2018).

[53] Tanju, E. H. ve Gönen, M., 4-5 yaş grubu zihinsel engelli çocuklara şekil kavramının kazandırılmasında bilgisayar destekli eğitimin etkisi, Çocuk Gelişimi ve Eğitimi Dergisi, 3(2), 81-92, (2006).

[54] Öztürk, D., Bilgisayar oyunlarının çocukların bilişsel ve duyuşsal gelişsimleri üzerindeki etkisinin incelenmesi, Yayımlanmamış Yüksek Lisans Tezi, Dokuz Eylül Üniversitesi Eğitim Bilimleri Enstitüsü, İzmir, (2007).

[55] Esen, B., Matematik eğitiminde ilköğretim 6. sınıflarda olasılık konusunun öğretiminde bilgisayar destekli eğitimin rolü, Yayımlanmamış Yüksek Lisans Tezi, Selçuk Üniversitesi Fen Bilimleri Enstitüsü, Konya, (2009).

[56] Singleton, C., ve Simmons, F., An evaluation of Wordshark in the classroom, British Journal of Educational Technology, 32(3), 317-330, (2001).

[57] Ruffin, M. A., The acquisition of inquiry skills and computer skills by 8th grade urban middle school students in a technology-supported environment, Saint Luis; University of Missouri, (2003).

[58] Christiensen, R., Effects of technology integration education on the attitudes of teachers and students, Journal of Research on Technology in Education, 34(4), 411-433, (2002).

[59] Yıldırım, S. ve Kaban., Öğretmen adaylarının bilgisayar destekli eğitime karş1 tutumları, Uluslararası İnsan Bilimleri Dergisi, 7 (2), 158-168, (2010).

[60] Adigüzel, O. C. ve Berk, Ş., Mesleki ve teknik ortaöğretim alan öğretmenlerinin bilgi gereksinimlerini karşılama kaynakları, Elektronik Sosyal Bilimler Dergisi, 8(29), 64-75, (2009).

[61] Aydoğdu, A., Ortaöğretim okullarında görev yapan coğrafya öğretmenlerinin bilgisayar destekli eğitime ilişkin tutumları, Yayınlanmamış Yüksek Lisans Tezi, Ankara Üniversitesi Sosyal Bilimler Enstitüsü, Ankara, (2003).

[62] Adıgüzel, A., İlköğretim okullarında öğretim teknolojilerinin durumu ve sınıf öğretmenlerinin bu teknolojileri kullanma düzeyleri, Dicle Üniversitesi Ziya Gökalp Eğitim Fakültesi Dergisi, (15), 1-17, (2010).

[63] Harris, J., The effects of computer games on young children: A review of the research, Journal of the American Academy of Child \& Adolescent, 72(22), 130, (2001).

[64] Gerardi, S., Use of computers/apps and the negative effects on children's intellectual outcomes, Sociology Mind, 7 (3), 128-132, (2017). 